\title{
IMPLEMENTASI CORPORATE SOCIAL RESPONSIBILTY (CSR) SEBAGAI MODEL MANAJEMEN PERUSAHAAN DALAM MENCAPAI KEUNGGULAN KOMPETITIF
}

\author{
Dede Jaelani \\ Sekolah Tinggi Ilmu Ekonomi STEMBI Bandung \\ Email: dedejaelani@stembi.ac.id
}

\begin{abstract}
Abstrak
Respon bisnis terhadap krisis harus melalui penyertaan dalam misinya untuk menciptakan nilai sosial di luar nilai ekonomi bagi pemegang saham. Namun, CSR bukan tentang bagaimana manfaat dibagikan tetapi tentang bagaimana manfaat itu diciptakan; Oleh karena itu, CSR harus dilihat sebagai model manajemen baru dan bukan sebagai alat pemasaran. Memasukkan CSR dalam organisasi memerlukan integrasi filosofi dan prinsip di semua tingkatan. Artikel ini bertujuan untuk menggali konsep CSR dan dimensinya, dalam dialog dengan pemangku kepentingan, dalam berbagai instrumen manajemen dalam hal tanggung jawab perusahaan, serta nilai strategisnya; sedemikian rupa sehingga perusahaan-perusahaan yang berhasil menyelaraskan pemangku kepentingan mereka dan melaksanakan akuntansi lingkungan yang bertanggung jawab, akan mencapai keunggulan kompetitif yang sulit untuk ditiru.
\end{abstract}

Kata Kunci: Tanggung Jawab Sosial Perusahaan, Perusahaan, Manajemen Rantai, Keunggulan Kompetitif.

\begin{abstract}
A business's response to a crisis must be through inclusion in its mission to create social value beyond economic value for shareholders. However, CSR is not about how benefits are shared but about how they are created; Therefore, CSR should be seen as a new management model and not as a marketing tool. Incorporating CSR in organizations requires the integration of philosophies and principles at all levels. This article aims to explore the concept of CSR and its dimensions, in dialogue with stakeholders, in various management instruments in terms of corporate responsibility, and the value of its strategy; in such a way that companies that successfully align their interests and implement responsible environmental accounting, will achieve a competitive advantage that is difficult to imitate.
\end{abstract}

Keywords: Corporate Social Responsibility, Corporate, Chain Management, Competitive Advantage

\section{A. PENDAHULUAN}

Saat ini, perusahaan tidak hanya memahami pentingnya masyarakat menerapkan kriteria yang bertanggung jawab dalam keputusan mereka, tetapi juga kegunaannya untuk kelangsungan dan pengembangan jangka panjang dari bisnis dan kegiatan mereka (Wu \& Pagell, 2011; Calabrese dkk, 2019). Globalisasi dan kesadaran warga yang lebih baik membuka kemungkinan besar akses informasi dan pengetahuan. Ini menyiratkan bahwa masalah lokal dianggap global dan bahwa budaya bisnis, yang secara tradisional tidak jelas, saat ini dipengaruhi oleh pilihan publik, sering kali disalurkan melalui asosiasi sektor dan konsumen (Martens, 2006; Lee, 2011).

Tanggung jawab sosial perusahaan memiliki minat yang berkembang di kalangan akademisi dan profesional. Tanggung Jawab Sosial Perusahaan (CSR) adalah pilar 
fundamental budaya perusahaan dan tidak boleh digunakan oleh perusahaan sebagai lapisan solidaritas atau gerakan amal sederhana, karena salah satu aset terpenting organisasi dipertaruhkan (Djaballah dkk, 2017; Ziolo dkk, 2021). Bank Dunia mendefinisikan CSR sebagai istilah yang menggambarkan komitmen perusahaan untuk menginformasikan semua pemangku kepentingannya tentang operasi dan kegiatannya (Marzukiewicz, 2004). Perusahaan yang bertanggung jawab secara sosial mempertimbangkan cakupan penuh dampaknya terhadap masyarakat dan lingkungan ketika membuat keputusan, menyeimbangkan kebutuhan pemangku kepentingan dengan tujuan profitabilitas mereka. Komisi Eropa menambahkan bahwa menjadi bertanggung jawab secara sosial berarti tidak hanya memenuhi harapan hukum, tetapi melampaui kepatuhan dan berinvestasi lebih banyak dalam sumber daya manusia, lingkungan, dan hubungan dengan pemangku kepentingan (Lynch-Wood dkk, 2009). Sejalan dengan itu, Buku Hijau Uni Eropa mendefinisikan CSR sebagai integrasi sukarela, oleh perusahaan-perusahaan yang memiliki kepedulian sosial dan lingkungan dalam operasi komersial mereka dan hubungan mereka dengan lawan bicara mereka (Longo dkk, 2005). Perserikatan Bangsa-Bangsa, pada bagiannya mengungkapkan bahwa perusahaan memiliki tanggung jawab sosial dan kewajiban moral untuk menggunakan kekuatan pasar untuk menjadikan globalisasi sebagai kekuatan positif bagi semua (Dusuki, 2008; New, 2015).

Seperti dapat dilihat, alasan implmenetasi CSR adalah karena perusahaan memiliki komitmen di luar tanggung jawab finansial dan komersial (Hopkins, 2016). Selanjutnya, sebagian besar definisi menyiratkan etika bisnis dan relevansi pemangku kepentingan di luar pemilik (Schmidheiny \& Zorraquin, 1997). Dengan kata lain, CSR telah menjadi kegiatan kunci di banyak perusahaan karena dianggap sebagai cara yang tepat untuk bertindak (Gan, 2006). CSR, dipahami dengan baik, bukan tentang bagaimana manfaat dibagikan tetapi tentang bagaimana manfaat itu diciptakan. Oleh karena itu, CSR harus hadir dari definisi misi hingga model manajemen bisnis. Kurangnya ketepatan dalam definisi CSR dan kebingungan dengan istilah lain seperti filantropi atau bahkan pemasaran karena suatu alasan terkadang menyebabkan CSR dipandang dengan kecurigaan.

Dalam pengertian ini, isi artikel ini berusaha agar pembaca memahami konsep Tanggung Jawab Sosial Perusahaan, serta faktor-faktor yang mengkondisikan perkembangannya, mengetahui area yang berbeda, salah satu tanggung jawab dilegitimasi di hadapan kelompok pengaruh yang berbeda (pemangku kepentingan) dan di hadapan masyarakat secara keseluruhan, mendekati instrumen dan alat utama manajemen yang bertanggung jawab, dan memahami ruang lingkup dan pentingnya menyelaraskan tujuan daya saing ekonomi global dengan tanggung jawab sosialnya ketika ingin mencapai komitmen untuk pembangunan berkelanjutan.

\section{B. METODE}

Analisis deskriptif dengan pendekatan kualitatif digunakan dalam penelitian ini. Meneliti masalah sosial atau kemanusiaan dengan menggunakan metode kualitatif adalah cara untuk memahami makna yang diberikan oleh beberapa individu atau kelompok untuk masalah ini. Pertanyaan dan proses, pengumpulan dan analisis data, analisis data induktif, dan interpretasi data adalah bagian dari proses penelitian kualitatif yang membutuhkan banyak langkah. Pendekatan kualitatif didefinisikan oleh tujuan penelitian yang bertujuan untuk memahami gejala dengan cara yang tidak selalu membutuhkan kuantifikasi, menurut Lewis (2015). Data penelitian dikumpulkan melalui penggunaan instrumen penelitian khusus. Observasi dan wawancara menjadi dasar dari penelitian ini. Temuan ini berasal dari sumber primer yang memberikan data langsung kepada peneliti. Dari sumber utama inilah informasi diperoleh dari subjek yang saat ini sedang diselidiki. Data ini biasanya diperoleh melalui publikasi akademik, artikel berita, dan catatan tulisan tangan. 


\section{HASIL DAN PEMBAHASAN}

\section{Para Pemangku Kepentingan}

Pendekatan pemangku kepentingan ada dua. Dari sudut pandang regulasi atau etika, perusahaan harus memperhatikan kepentingan sah semua pemangku kepentingan dan menerapkan kebijakan yang memfasilitasi integrasi mereka ke dalamnya (Polonsky, 1995). Di sisi lain, dari sudut pandang instrumental, bahwa perusahaan memperoleh "lisensi untuk bertindak" menyiratkan memiliki tujuan untuk berhasil di pasar dan menghilangkan semua hubungan dengan pemangku kepentingan yang tidak produktif. Bagaimanapun, baik karena satu dan lain alasan dimasukkannya CSR dalam model bisnis, diperlukan dialog yang komprehensif dan permanen dengan para pemangku kepentingan (Perrini dkk, 2007).

Manajemen pemangku kepentingan disajikan, dengan cara ini, sebagai cara alami untuk menciptakan nilai bersama bagi kelompok kepentingan yang berbeda dan merupakan dasar untuk berinovasi dan meningkatkan proses dan manajemen risiko, dengan mempelajari praktik yang baik dari pemangku kepentingan mereka sendiri, dan untuk mencapai tujuan yang Perusahaan tidak dapat mencapainya secara terpisah dan mengarah pada pembangunan sosial yang lebih adil dan berkelanjutan (Schneider dkk, 2010). Tidak mengherankan, pada tahun 1963 Stanford Research Institute mendefinisikan untuk pertama kalinya pemangku kepentingan sebagai "semua kelompok yang tanpa dukungannya organisasi tidak dapat berhenti eksis, yang memaksa perusahaan untuk tidak hanya berfokus pada pemegang saham" (Freeman \& Velamuri, 2006).

Respon bisnis terhadap krisis tentu harus melalui penyertaan dalam misinya menciptakan nilai sosial di luar nilai ekonomi bagi pemegang saham seperti yang di kemukakan, model bisnis juga harus diresapi oleh CSR. Ini memerlukan perpindahan dari model bisnis tradisional, yang berupaya memaksimalkan manfaat bagi pemilik dan memahami pemegang saham, pemasok, dan pekerja sebagai input bagi perusahaan dan pelanggan sebagai penerima outputnya ke model pemangku kepentingan (Atkin \& Skitmore, 2008), yang memahami perusahaan sebagai organisasi sosial ekonomi yang diciptakan untuk menghasilkan kekayaan bagi para pemangku kepentingan yang berbeda yang membentuknya, dan di mana manfaat dan kepentingan perusahaan dan pemangku kepentingannya saling menguntungkan.

Pada model pertama, perusahaan membatasi dirinya untuk meningkatkan keuntungannya sambil menghormati aturan main. Pendekatan instrumental CSR adalah bagian dari model keuangan atau kepemilikan saham ini, di mana pemegang saham adalah pemangku kepentingan utama dan kelompok kepentingan lainnya adalah instrumen untuk memaksimalkan nilai pemilik dalam jangka panjang. Sebaliknya, pendekatan normatif CSR termasuk dalam model yang lebih maju, di mana pemangku kepentingan dianggap apa yang mereka wakili dalam diri mereka sendiri dan bukan untuk kegunaannya bagi pemangku kepentingan lainnya. Dalam pengertian ini, menurut Doh \& Guay (2006), berpindah dari ekonomi ke tanggung jawab sosial menyiratkan bahwa perusahaan berkembang dari model ekonomi ke model sosial ekonomi. Ketika perusahaan menyadari antropologi sosialnya, perilaku sosial adalah sesuatu yang alami dan terkonsolidasi, dan dialog dengan lawan bicara yang berbeda dipahami sebagai cara untuk memanfaatkan peluang dan mengelola risiko di berbagai bidang lingkungan: ekonomi, sosial, dan lingkungan.

Menurut pendapat Van Riel (2012), yang telah mempelajari banyak kasus bisnis dalam beberapa tahun terakhir, perusahaan yang paling sukses telah memahami bahwa strategi terbaik akan gagal jika tidak mendapat dukungan dari pemangku kepentingan utama. Dengan demikian, memulai dialog dengan pemangku kepentingan melibatkan identifikasi dan prioritas mereka. Dari sudut pandang hubungan, mereka biasanya diklasifikasikan sebagai internal (pemegang saham, pemilik, karyawan) dibandingkan dengan eksternal (pelanggan, pemasok, kreditur, administrasi, masyarakat, media); meskipun juga umum untuk membedakan antara struktural (investor, pemegang saham), manajemen (pemasok, klien, karyawan, kreditur) dan 
pelengkap (administrasi, masyarakat, media). Memprioritaskan pemangku kepentingan juga berarti mengklasifikasikan mereka menurut dampaknya terhadap perusahaan menjadi kritis, dasar dan pelengkap. Oleh karena itu, perusahaan harus menganalisis semua hubungannya saat ini dan menentukan hubungan yang akan dihilangkan, dipertahankan, atau ditambahkan di masa depan. Mengetahui pemangku kepentingan memungkinkan perusahaan untuk memberikan tanggapan yang efektif kepada mereka. Menurut Savage dkk. (1991), perlu untuk menganalisis potensi pemangku kepentingan untuk mengancam perusahaan dan kecenderungan mereka untuk bekerja sama. Sedemikian rupa sehingga jika kelompok kepentingan bukan kolaborator, perusahaan harus mempertahankan diri dari yang paling kuat dan mengendalikan yang kurang relevan. Sebaliknya, dari perspektif yang lebih proaktif, jika pemangku kepentingan adalah kolaborator, perusahaan harus berkolaborasi dengan yang paling penting dan mencoba melibatkan orang lain. Hubungan ini dapat terwujud dalam presentasi perusahaan yang sederhana, dalam forum dialog, dalam studi pasar, dalam survei kepuasan atau bahkan dalam proyek dan aliansi bersama.

Hubungan yang efektif dan selaras secara strategis dengan pemangku kepentingan membantu perusahaan dan pemangku kepentingan untuk mengenal satu sama lain lebih baik dan membangun iklim kepercayaan di antara mereka yang memungkinkan peningkatan manajemen risiko dan reputasi. Di sisi lain, mereka berkontribusi untuk menginformasikan dan mendidik pemangku kepentingan dan lingkungan bisnis dan, akibatnya, untuk mencapai pembangunan yang lebih berkelanjutan dan adil. Akhirnya, mereka berkontribusi untuk menjawab masalah dan kepentingan yang tidak dapat diselesaikan secara terpisah.

\section{Dimensi CSR}

CSR sering didefinisikan sebagai konsep multidimensi. Sekarang, tidak semua definisi menunjuk ke dimensi yang sama. Carroll (1991) mengklasifikasikan dimensi CSR menurut jenis tanggung jawabnya:

a. Dimensi ekonomi. Menjadi menguntungkan, menghasilkan keuntungan, menjadi efisien adalah salah satu tanggung jawab paling dasar dari sebuah perusahaan.

b. Dimensi hukum. Perusahaan diharuskan untuk mematuhi undang-undang dan peraturan, mematuhi aturan anti-korupsi, dan memenuhi kewajiban kontraktual mereka.

c. Dimensi etika. Perusahaan diharapkan untuk menghindari praktik yang meragukan, mematuhi semangat hukum, bertindak sesuai dengan kriteria etika.

d. Dimensi filantropi. Sangat diharapkan bahwa perusahaan menginvestasikan sebagian dari sumber daya mereka di komunitas tempat mereka didirikan, bahwa mereka berkolaborasi dalam proyek dan program untuk perbaikan sosial, yang berkontribusi pada pembangunan sosial.

Selanjutnya, Schwartz \& Carroll (2003) mengkonseptualisasikan CSR dalam model yang menggabungkan dimensi ekonomi, hukum dan etika tanggung jawab, menganalisis hubungan di antara mereka dan mengklasifikasikan tindakan CSR berdasarkan hubungan tersebut.

Di sisi lain, Green Paper of the European Commission (2001) lebih menekankan pada praktik CSR di dalam dan di luar perusahaan, dengan membedakan dua dimensi:

a. Dimensi internal. Di dalam perusahaan, CSR membuka cara baru untuk mengelola perubahan dan mendamaikan pembangunan sosial dengan peningkatan daya saing, melalui praktik yang bertanggung jawab dalam sumber daya manusia dan kesehatan dan keselamatan kerja, tetapi juga dalam pengelolaan sumber daya alam yang digunakan dalam produksi.

b. Dimensi eksternal. CSR meluas ke masyarakat lokal dan mencakup berbagai pemangku kepentingan seperti mitra bisnis dan pemasok, konsumen, otoritas publik dan LSM yang membela kepentingan masyarakat lokal dan lingkungan. Di dunia yang dicirikan 
oleh investasi multinasional dan rantai produksi lepas pantai, tanggung jawab sosial perusahaan juga harus melampaui batas-batas Eropa dan memastikan penghormatan terhadap hak asasi manusia dan lingkungan.

Keterlibatan masyarakat dan pembangunan lokal, integrasi penyandang disabilitas dan kepentingan konsumen, termasuk privasi, juga menjadi bagian dari agenda CSR. Diakui bahwa promosi tanggung jawab sosial dan lingkungan dalam rantai pasokan dan pengungkapan informasi non-keuangan merupakan aspek lintas sektoral yang penting".

Terakhir, CSR juga terkait dengan tiga pilar pembangunan berkelanjutan: sosial, lingkungan, dan ekonomi. Laporan Brundtland, yang dipresentasikan pada tahun 1987 oleh Komisi Dunia PBB untuk Lingkungan dan Pembangunan, mendefinisikan pembangunan berkelanjutan sebagai "apa yang memenuhi kebutuhan saat ini tanpa mengorbankan kemampuan generasi mendatang untuk memenuhi kebutuhan mereka sendiri."

a. Dimensi ekonomi: yang menyiratkan tidak mengkonsumsi lebih banyak sumber daya daripada yang diperlukan atau di atas kapasitas regenerasinya.

b. Dimensi lingkungan: tidak menghasilkan polutan pada tingkat yang lebih tinggi dari yang dapat diserap, didaur ulang atau dinetralisir oleh lingkungan.

c. Dimensi sosial: Jangan membahayakan generasi mendatang, atau menyebabkan perbedaan sosial.

Dengan demikian, tanggung jawab perusahaan tidak hanya sebatas keberadaannya tetapi juga tanggung jawab antargenerasi. Studi tentang tiga dimensi ini adalah dasar untuk mengidentifikasi perusahaan terbaik untuk berinvestasi.

\section{Manajemen CSR}

CSR harus transparan dan bukan proses dekoratif yang digunakan sebagai mekanisme untuk meningkatkan reputasi. Di satu sisi, banyak perusahaan mencerminkan beberapa elemen tanggung jawab sosial dalam pernyataan atau tujuan umum organisasi yang berada dalam domain publik; seperti halnya misi, visi, dan nilai-nilai perusahaan (De Grosbois, 2012). Di sisi lain, semakin banyak perusahaan besar yang memahami pentingnya standarisasi CSR. Namun, dalam praktiknya terdapat keragaman besar cara perusahaan menerapkan standar ini (Kolk \& Tulders, 2010).

Mengikuti kriteria ada lima instrumen paling umum yang harus dihadirkan perusahaan untuk dianggap sebagai organisasi yang mendukung gagasan CSR:

a. Pernyataan perusahaan. Mereka adalah dokumen sederhana dan singkat yang berfungsi sebagai pedoman umum untuk kebijakan perusahaan, dan yang menentukan nilai-nilai perusahaan, budaya organisasinya.

b. Kode etik. Mereka mematuhi kebutuhan untuk mengatur perilaku anggota perusahaan sesuai dengan prinsip-prinsip etika. Kode-kode ini dapat dirancang di tingkat bisnis atau sektor. Beberapa perusahaan, lebih dan lebih, alih-alih menyusun kode mereka sendiri, memutuskan untuk mematuhi United Nations Global Compact, yang didasarkan pada 10 prinsip mengenai hak asasi manusia, tenaga kerja, lingkungan dan sosial-ekonomi.

c. Kebijakan CSR. Mekanisme yang diterapkan oleh manajemen senior untuk menentukan tujuan dan prioritas serta memandu perusahaan menuju manajemen yang etis dan bertanggung jawab. Di satu sisi, itu adalah kerangka di mana instrumen lain dimasukkan.

d. Sistem manajemen yang harmonis. Instrumen yang dikenal dan diterima di berbagai bidang seperti kualitas, lingkungan, keselamatan kerja, dll. Karena bersifat homogen di semua perusahaan yang menerapkannya, instrumen tersebut memfasilitasi verifikasi internal dan eksternal dan memungkinkan perbandingan. Dalam kasus khusus CSR, perlu disebutkan SA 8000, berfokus pada kondisi kerja dan dirancang untuk pemasok dan pemasok perusahaan besar; ISO 26000, panduan yang menetapkan garis tindakan 
dalam hal CSR, tetapi tidak sertifikasi; dan SGE21, sistem manajemen tanggung jawab sosial Eropa pertama yang memungkinkan, atas dasar sukarela, proses audit dan pencapaian sertifikasi dalam Manajemen Etis dan Tanggung Jawab Sosial.

e. Laporan sosial dan lingkungan. Dokumen yang menawarkan informasi lengkap tentang hasil sosial dan lingkungan, sehingga memungkinkan perbandingan hasil berdasarkan kriteria umum. Laporan keberlanjutan, misalnya, memaksa perusahaan untuk mempresentasikan inisiatif dan hasil mereka secara publik. Dalam pengertian ini, standar jaminan AA1000 adalah standar aplikasi umum untuk mengevaluasi, bersaksi, dan memperkuat kredibilitas dan kualitas laporan keberlanjutan organisasi dan proses utamanya. Tapi inisiatif internasional yang paling penting dalam hal komunikasi CSR adalah Global Reporting Initiative (GRI), yang tujuannya adalah agar perusahaan melaporkan hasil sosial dan lingkungan mereka menggunakan kriteria umum. Penggunaan yang dibuat oleh investor dan konsumen dari laporan "tiga keseimbangan", seperti yang dipromosikan oleh GRID, dapat secara substansial mengkondisikan manajemen CSR.

Menurut Baumgartner (2014), perusahaan, dalam kerangka keunikan mereka dan berdasarkan nilai-nilai perusahaan mereka, dapat menyesuaikan berbagai instrumen manajemen CSR dengan harapan objektif mereka dalam hal tanggung jawab sosial, sementara mekanisme ini berfungsi untuk menyeragamkan dan meratakan kriteria dan menyesuaikan prosedur internal mereka dengan filosofi CSR.

\section{Nilai Strategis CSR}

Menurut survei yang dilakukan oleh United Nations Global Compact and Accenture di antara 1.000 eksekutif senior dari seluruh dunia1, 78\% dari mereka menganggap keberlanjutan sebagai cara pertumbuhan dan inovasi dan, di samping itu, 79\% percaya bahwa hal itu dapat berarti persaingan keuntungan di sektor Anda. Meskipun mengakui bahwa situasi ekonomi dan prioritas lainnya menimbulkan hambatan bagi integrasi keberlanjutan di perusahaan mereka, $84 \%$ percaya bahwa dunia bisnis harus memimpin upaya untuk mengatasi tantangan keberlanjutan. Terlepas dari kenyataan bahwa efek positif dari praktik CSR pada masyarakat tidak dapat disangkal, hubungan antara CSR dan kinerja bisnis masih dapat diperdebatkan (Khojastehpour \& Johns, 2014).

Jika perusahaan menganalisis pilihan CSR mereka dengan cara yang sama seperti mereka memilih bisnis utama mereka, mereka akan menemukan bahwa CSR dapat menjadi sumber keunggulan kompetitif (Saeed \& Arshad, 2012). Seperti yang ditunjukkan oleh Schwartz \& Carroll (2003), banyak tindakan yang dianggap etis dapat secara tidak langsung dikaitkan dengan manfaat ekonomi jangka panjang. Namun, nilai strategis CSR dipertanyakan dari sudut pandang teori neoklasik, yang tidak mudah mendamaikan kesejahteraan sosial dengan keuntungan perusahaan karena pasar yang tidak sempurna tidak memaksimalkan kesejahteraan sosial (Allison, 2004). Faktanya, penelitian yang menganalisis hubungan ini menawarkan hasil yang beragam. Menurut Maxfield (2011), sementara ketidaksempurnaan pasar (eksternalitas, informasi asimetris dan kolusi) sebagian menjelaskan perlunya CSR, mereka pada saat yang sama merupakan sumber keunggulan kompetitif. Di satu sisi, dalam menghadapi kegagalan pasar, masyarakat menuntut sikap bertanggung jawab dalam perusahaan. Di sisi lain, dari perspektif Sumber Daya dan Kapasitas, praktik CSR dapat digunakan sebagai strategi diferensiasi, jika dan hanya jika perusahaan mampu mencegah pesaing mereka untuk meniru strategi mereka (McWilliams dkk, 2006). Dalam pengertian ini, Van Riel (2012) menunjukkan bahwa perusahaan-perusahaan yang berhasil menyelaraskan kelompok kepentingan mereka akan mencapai keunggulan kompetitif yang sulit untuk ditiru.

Nilai strategis CSR bagi perusahaan harus dilihat dari pengelolaan rantai nilainya yang bertanggung jawab. Menurut penelitian yang dilakukan Boehe \& Cruz (2010) terdapat 
hubungan langsung antara pengelolaan sumber daya manusia dan hasil ekonomi perusahaan, sedemikian rupa sehingga pihak yang mengelola lebih memadai. kepada karyawan Anda, mengurangi biaya dan menghasilkan pendapatan yang lebih tinggi. Sejalan dengan itu, Van Riel (2012) menyatakan bahwa peningkatan $10 \%$ dalam keselarasan karyawan menyiratkan peningkatan $6 \%$ dalam upaya mereka, yang memerlukan peningkatan $2 \%$ dalam hasil keuangan. Selanjutnya, ketika sebuah perusahaan memutuskan untuk bertindak dengan cara yang bertanggung jawab secara sosial, model manajemen dan proses internalnya harus berubah dan ini harus dikomunikasikan secara memadai kepada anggotanya untuk mendukung manajemen perubahan. Namun, yang sama pentingnya atau lebih penting daripada komunikasi internal adalah eksternal: perusahaan harus mengomunikasikan dan menyebarkan CSR-nya.

Menurut Scandelius \& Cohen (2016), hanya melalui komunikasi dan strategi CSR yang terintegrasi kepercayaan pemangku kepentingan dapat tercapai. Menurutnya, binomial yang terdiri dari "komunikasi" plus "tanggung jawab" menawarkan banyak kemungkinan bagi perusahaan, sehingga perlu memanfaatkannya dan menggerakkan roda gigi menuju inovasi dan kreativitas. Dengan cara ini, bentuk komunikasi yang lebih tradisional, seperti sponsorship atau periklanan, tidak hilang tetapi diperkuat oleh alat digital baru, lebih gesit, lebih murah, lebih langsung dan, umumnya, dengan jangkauan yang lebih luas. Penciptaan dan pengelolaan pengetahuan diperlukan untuk mencapai inovasi ini karena, seperti yang ditunjukkan Maxfield (2011), kemungkinan besar kegiatan CSR yang terkait langsung dengan strategi inovasi lebih menguntungkan daripada yang berorientasi pada hubungan masyarakat atau pemasaran. Di sisi lain, sebagai konsekuensi dari globalisasi, perusahaan berpartisipasi dalam jaringan pemasok di tingkat internasional, yang membuat mereka mempertimbangkan untuk memperluas kegiatan CSR mereka ke seluruh rantai nilai.

\section{Tantangan Untuk CSR}

Terlepas dari dampak buruk yang ditimbulkan oleh krisis, terutama dalam memperdalam kesenjangan sosial, juga benar bahwa situasi ini memberi kita kesempatan untuk memikirkan kembali model produksi kita dan untuk memperkuat ekonomi berdasarkan kemajuan dan keberlanjutan. yang dalam beberapa hal menjamin daya saingnya dalam jangka panjang. Dalam konteks ini, CSR disajikan sebagai alternatif masa depan yang baik untuk model ekonomi berdasarkan kekuatan pasar dan spekulasi. Jika sistem keuangan tidak mendorong hutang berlebih, jika keberadaan surga pajak tidak mendorong korupsi, jika visi bisnis jangka pendek tidak melupakan perlindungan lingkungan dan hak asasi manusia, kita tidak akan mengalami masalah ekonomi, sosial dan lingkungan. krisis yang begitu besar. Oleh karena itu, CSR seharusnya tidak hanya dipahami sebagai solusi tetapi lebih sebagai kebutuhan untuk mengubah sistem yang telah gagal. Seperti yang telah kita lihat, CSR dan komunikasi harus berjalan beriringan, terutama dengan bantuan teknologi informasi baru, tetapi CSR harus dilihat sebagai model manajemen baru dan bukan sebagai alat pemasaran. Memasukkan CSR dalam organisasi melibatkan pengintegrasian filosofi dan prinsip-prinsipnya di semua tingkatan. Keputusan mungkin datang dari tingkat perusahaan, tetapi pelaksanaan dan dialog dengan pemangku kepentingan harus turun ke pekerjaan, melewati bisnis dan departemen yang berbeda. Di sisi lain, penerapan CSR harus mencari keseimbangan antara dimensinya; yaitu antara CSR internal dan eksternal, antara tujuan ekonomi, sosial dan lingkungan. Namun pengintegrasian konsep multidimensi secara seimbang hanya dapat dicapai melalui pendekatan transversal yang secara bertahap menggantikan unit fungsional tertentu CSR dengan komite atau komisi multifungsi yang memiliki kapasitas untuk mengkoordinasikan dan melaporkan tanggung jawab sosial, serta mendapat dukungan dari pihak eksternal. dewan penasehat, sehingga semua pemangku kepentingan terwakili. Lebih jauh lagi, akan lebih baik bagi perusahaan yang telah berkomitmen sampai batas tertentu dengan CSR, untuk memperluas dan memperdalam berbagai bidang tindakan dalam hal tanggung jawab, untuk mengevaluasi 
praktik mereka dan membuat kemajuan dalam verifikasi dan sertifikasi eksternal. Dialog dengan pemangku kepentingan tidak dapat dicapai dalam semalam, karena menghasilkan sumber daya tidak berwujud yang sangat sulit untuk ditiru dan, oleh karena itu, merupakan sumber keunggulan kompetitif. Tantangan terbesar bagi CSR mungkin adalah penerapannya di UMKM. Saat ini, banyak UMKM yang jauh dari konsep ini. Namun, jika perusahaanperusahaan ini ingin bertahan dalam lingkungan yang kompetitif, mereka harus mampu menunjukkan bahwa mereka mencapai parameter tanggung jawab sosial tertentu. Tentu tindakan mereka tidak dapat memiliki cakupan perusahaan besar tetapi ukuran dan fleksibilitas mereka juga dapat memberi mereka keuntungan untuk berspesialisasi dalam bidang CSR tertentu, dalam pemangku kepentingan tertentu atau di beberapa ceruk pasar yang menghargai spesialisasi itu secara tepat. Ada pepatah Cina yang mengatakan "ketika angin perubahan bertiup, ada yang membangun tembok; lainnya, pabrik". Kami memiliki pengetahuan, sumber daya, dan rencana aksi untuk mengubah sistem. Sekarang hanya masalah perusahaan yang mengenali kemungkinan ekonomi dan sosial yang terbuka bagi mereka dan mengumpulkan keinginan untuk berubah.

\section{KESIMPULAN}

Tanggung Jawab Sosial Perusahaan (CSR) merupakan suatu bentuk komitmen perusahaan untuk memberitahukan kepada seluruh stakeholder tentang operasi dan kegiatan dan merupakan suatu bentuk tanggung jawab sosial perusahaan kepada masyarakat dan lingkungan sekitarnya sebagai tanggung jawab atas dampak yang ditimbulkan dari proses produksi mereka. Dalam pelaksanan CSR pemangku kepentingan memainkan peranan yang sangat penting karena dengan adanya hubungan yang efektif dan selaras secara strategis dengan pemangku kepentingan membantu perusahaan dan pemangku kepentingan untuk mengenal satu sama lain lebih baik dan membangun iklim kepercayaan di antara mereka yang memungkinkan peningkatan manajemen risiko dan reputasi. Untuk dimensi CSR dari segi tanggung jawab dibagi kedalam ekonomi, hukum, etika dan filantropi. Sementara dari praktik di CSR di dimensi internal dan eksternal. Didalam manajemen CSR harus transparan dan mencerminkan tanggung jawab sesuai dengan tujuan organisasi. Ada lima kriteria untuk perusahaan dianggap sebagai organisasi yang mendukung gagasan CSR: 1) Pernyataan perusahaan; 2) Kode etik; 3) Kebijakan CSR; 4) Sistem Manajemen dan 5) Laporan sosial dan lingkungan. Jika perusahaan menganalisis pilihan CSR mereka dengan cara yang sama seperti mereka memilih bisnis utama mereka, mereka akan menemukan bahwa CSR dapat menjadi sumber keunggulan kompetitif, hal ini disebabkan ketika menghadapi kegagalan pasar, masyarakat menuntut sikap bertanggung jawab dalam perusahaan. Di sisi lain, dari perspektif Sumber Daya dan Kapasitas, praktik CSR dapat digunakan sebagai strategi diferensiasi.

\section{REFERENSI}

Atkin, B., \& Skitmore, M. (2008). Stakeholder Management in Construction. Construction Management and Economics, 26(6), 549-552.

Baumgartner, R. J. (2014). Managing Corporate Sustainability and CSR: A Conceptual Framework Combining Values, Strategies and Instruments Contributing to Sustainable Development. Corporate Social Responsibility and Environmental Management, 21(5), 258-271.

Boehe, D. M., \& Cruz, L. B. (2010). Corporate Social Responsibility, Product Differentiation Strategy and Export Performance. Journal of Business ethics, 91(2), 325-346.

Calabrese, A., Costa, R., Levialdi, N., \& Menichini, T. (2019). Integrating Sustainability into Strategic Decision-Making: A Fuzzy AHP Method for the Selection of Relevant Sustainability Issues. Technological Forecasting and Social Change, 139, 155-168. 
Carroll, A. B. (1991). The Pyramid of Corporate Social Responsibility: Toward the Moral Management of Organizational Stakeholders. Business Horizons, 34(4), 39-48.

Creswell, J. W., \& Miller, D. L. (2000). Determining Validity in Qualitative Inquiry. Theory into Practice, 39(3), 124-130.

De Grosbois, D. (2012). Corporate Social Responsibility Reporting by the Global Hotel Industry: Commitment, Initiatives and Performance. International Journal of Hospitality Management, 31(3), 896-905.

Djaballah, M., Hautbois, C., \& Desbordes, M. (2017). Sponsors' CSR strategies in sport: A Sensemaking Approach of Corporations Established in France. Sport Management Review, 20(2), 211-225.

Doh, J. P., \& Guay, T. R. (2006). Corporate Social Responsibility, Public Policy, and NGO Activism in Europe and the United States: An Institutional- Stakeholder Perspective. Journal of Management studies, 43(1), 47-73.

Dusuki, A. W. (2008). What Does Islam Say About Corporate Social Responsibility. Review of Islamic Economics, 12(1), 5-28.

Freeman, R. E., \& Velamuri, S. R. (2006). A New Approach to CSR: Company Stakeholder Responsibility. In Corporate Social Responsibility (pp. 9-23). Palgrave Macmillan, London.

Gan, A. (2006). The Impact of Public Scrutiny on Corporate Philanthropy. Journal of Business Ethics, 69(3), 217-236.

Hopkins, M. (2016). The Planetary Bargain: Corporate Social Responsibility Comes of Age. Springer.

Khojastehpour, M., \& Johns, R. (2014). The Effect of Environmental CSR Issues on Corporate/Brand Reputation and Corporate Profitability. European Business Review.

Kolk, A., \& Van Tulder, R. (2010). International Business, Corporate Social Responsibility and Sustainable Development. International Business Review, 19(2), 119-125.

Lee, M. D. P. (2011). Configuration Of External Influences: The Combined Effects of Institutions and Stakeholders on Corporate Social Responsibility Strategies. Journal of Business Ethics, 102(2), 281-298.

Lewis, S. (2015). Qualitative inquiry and research design: Choosing among five approaches. Health promotion practice, 16(4), 473-475.

Longo, M., Mura, M., \& Bonoli, A. (2005). Corporate Social Responsibility and Corporate Performance: The Case of Italian Smes. Corporate Governance: The international Journal of Business in Society.

Lynch- Wood, G., Williamson, D., \& Jenkins, W. (2009). The Over- Reliance on SelfRegulation in CSR Policy. Business Ethics: A European Review, 18(1), 52-65.

Martens 1, S. (2006). Public Participation with Chinese Characteristics: Citizen Consumers in China's Environmental Management. Environmental Politics, 15(02), 211-230.

Maxfield, S. (2011). Teaching Economics to Business Students through the Lens of Corporate Social Responsibility and Sustainability. Journal of Economic Education, 42(1), 60-69.

Mazurkiewicz, P. (2004). Corporate Environmental Responsibility: is A Common CSR Framework Possible. World Bank, 2, 1-18.

McWilliams, A., Siegel, D. S., \& Wright, P. M. (2006). Corporate Social Responsibility: Strategic Implications. Journal of Management Studies, 43(1), 1-18.

New, S. J. (2015). Modern Slavery and the Supply Chain: The Limits of Corporate Social Responsibility? Supply Chain Management: An International Journal.

Perrini, F., Russo, A., \& Tencati, A. (2007). CSR Strategies of SMES and Large Firms. Evidence from Italy. Journal of Business Ethics, 74(3), 285-300.

Polonsky, M. J. (1995). A Stakeholder Theory Approach to Designing Environmental Marketing Strategy. Journal of Business \& Industrial Marketing. 
Saeed, M. M., \& Arshad, F. (2012). Corporate Social Responsibility as a Source of Competitive Advantage: The Mediating Role of Social Capital and Reputational Capital. Journal of Database Marketing \& Customer Strategy Management, 19(4), 219-232.

Savage, G. T., Nix, T. W., Whitehead, C. J., \& Blair, J. D. (1991). Strategies for Assessing and Managing Organizational Stakeholders. Academy of Management Perspectives, 5(2), 61-75.

Scandelius, C., \& Cohen, G. (2016). Achieving Collaboration with Diverse Stakeholders-The Role of Strategic Ambiguity in CSR Communication. Journal of Business Research, 69(9), 3487-3499.

Schmidheiny, S., \& Zorraquin, F. (1997). Financing Change: The Financial Community, EcoEfficiency and Sustainable Development. In Fletcher Forum of World Affairs (Vol. 21, No. 1).

Schneider, F., Kallis, G., \& Martinez-Alier, J. (2010). Crisis or Opportunity? Economic Degrowth for Social Equity and Ecological Sustainability. Introduction to This Special Issue. Journal of Cleaner Production, 18(6), 511-518.

Schwartz, M. S., \& Carroll, A. B. (2003). Corporate Social Responsibility: A Three-Domain Approach. Business Ethics Quarterly, 13(4), 503-530.

Van Riel, C. B. (2012). The Alignment Factor: Leveraging the Power of Total Stakeholder Support. Routledge.

Wu, Z., \& Pagell, M. (2011). Balancing Priorities: Decision-Making in Sustainable Supply Chain Management. Journal of Operations Management, 29(6), 577-590.

Ziolo, M., Filipiak, B. Z., \& Tundys, B. (2021). Corporate Social Responsibility and Sustainable Value Creation. In Sustainability in Bank and Corporate Business Models (pp. 67-110). Palgrave Macmillan, Cham. 